\title{
Behaviour in first year after drug dependent pregnancy
}

\author{
A L VAN BAAR, * P FLEURY, $\dagger$ AND C A ULTEE \\ ${ }^{*}$ Department of Neonatology and + Department of Neurology, Academic Medical Centre, Amsterdam
}

SUMmaRY Neurobehavioural development of a group of 35 infants of drug dependent mothers and of a reference group of 37 infants was compared. Two tailed testing showed that at the age of 3 months the infants of drug dependent mothers seemed to be more active than the reference group; at 6 months, however, no difference was found. On the infant behaviour temperament questionnaire, infants of drug dependent mothers tended to have slightly better scores for 'duration of orienting' at the age of 9 months; five other dimensions of behaviour did not differ between the groups. The Bayley scales of infant development and neurological examination according to the method of Touwen did not show any significant differences among the groups at the ages of 6 or 12 months. At 12 months infants of drug dependent mothers had slightly but not significantly worse results on electroencephalography. Studied with multidisciplinary measurements, the development of infants of drug dependent mothers does not seem to diverge particularly from the development of the reference group.

Little information is available about the long term development of infants of drug dependent mothers. Results of research on the development of such children after the neonatal period are also inconsistent. ${ }^{1}$ Moderate withdrawal symptoms can still appear during the first six months (the subacute abstinence syndrome). ${ }^{2}$ Some authors report continued sleep disturbances, ${ }^{2}$ and disturbances of physical growth. ${ }^{3}$ Neurological evaluations have shown more tone abnormalities, strabismus, and nystagmus with children exposed to methadone during the first three years of life. ${ }^{4}$

Concerning cognitive and motor development some investigators have found differences between infants of drug dependent mothers and reference groups on the Bayley scales, ${ }^{45}$ but others did not. ${ }^{67}$ Advanced motor performance in early infancy, as well as a transitory delay in motor development towards the end of the first year, have been noted. ${ }^{8-9}$ Follow up of infants of drug dependent mothers is especially difficult because of unreliable behaviour of many addicted mothers. ${ }^{4}$ Infants of drug dependent mothers may, however, need specific intervention or support during development, and multidisciplinary, long term evaluation is needed for a better perspective of the processes concerned.

In a prospective longitudinal study the early development of infants of drug dependent mothers was examined with various measurements and compared with the development of a reference group of infants whose mothers did no take drugs and who were born after trouble free pregnancies. The design of this study was aimed at detection of medium to large effects. ${ }^{10}$ The children were examined from birth to the age of 6 years on physical, neurological, behavioural, and socioemotional scales.

\section{Subjects and methods}

A group of 35 infants of drug dependent mothers whose mothers had been using heroin, cocaine, and methadone were enrolled in the study, and a group of 37 infants born at full term to mothers who did not use drugs during pregnancy served as a reference group. The infants were singletons and had no congenital anomalies. The groups of children are described in detail in the report on their neonatal examination. ${ }^{11}$

Two of the infants of drug dependent mothers were discharged from the hospital to a children's home, and five others went to children's homes, foster parents, or grandparents during the first year.

During this part of the study the parents of three children in the study group refused further cooperation; the parents of two other infants of drug 
dependent mothers moved to another country. Three of these children were preterm and two had no symptoms of the neonatal abstinence syndrome. Two of the mothers used heroin, cocaine, and methadone; the others used heroin and methadone. In the reference group one of the parents refused to cooperate after nine months.

Table 1 shows the examinations, and the number and mean age of the groups at each examination. Nine of the infants of drug dependent mothers were born preterm and in order to compared the infants of drug dependent mothers more precisely we have given the data for the whole group and also for a subgroup of infants born at full term to drug dependent mothers. All examinations of the preterm children were done at corrected age. Attendance of some of the subjects in the study group was erratic; at least four appointments were made to try to complete the examinations, but even this did not prevent variations in the amount of data available.

The neurological examination according to Touwen comprises items for movement, posture, reflexes, and reactions; these show a clear developmental trend. ${ }^{12}$ The items are scored on rating scales and the total score has been used for analysis.

Electroencephalographic output and activity of the infants were examined in the same manner as in the neonatal period with scores on electroencephalography varying from normal to borderline, suspect, or abnormal. ${ }^{1}$ The activity, or mobility, of the infants was observed during their baths. Gross motor movements were rated on a seven point scale from 1 (hypoactive) to 7 (hyperactive). ${ }^{13}$ Amount of activity was also one of the aspects of behaviour rated in a temperament questionnaire, the infant behaviour questionnaire, that was answered by the parents or guardians when the children were 9 months old. ${ }^{14}$ Other aspects of the questionnaire were the amount of smiling and laughter, reactions of fear or distress to novel or intense stimuli, reactions of distress to limitations, soothability, and 'duration of orienting'. The Dutch version of the Bayley scales of infant development was used at the age of 6 and 12 months. ${ }^{15}{ }^{16}$ Interobserver agreement for these measurements varied between $88 \%$ and $95 \%$.

\section{Results}

Nonparametric statistical tests are used because of the ordinal character of most of the results. Except for the analysis of the electroencephalography results (for which Fisher's exact probability test has been used) the Kruskal-Wallis analysis of variance was done. ${ }^{17}$ The study aimed to detect medium to large differences between the groups. Two tailed probability values of at least 0.15 are discussed; a $p$ value of 0.05 is accepted as significant, together with a power of at least $0 \cdot 80 .^{10}$

There were no differences between the groups on the neurological examinations at the age of 6 and 12 months.

Two children in the study group had a suspect or abnormal electroencephalogram at the age of 1 year compared with none of the reference children (table 2). The results show that the total group of infants of drug dependent mothers $(p=0 \cdot 15)$ as well as the subgroup born at full term $(p=0 \cdot 12)$ seem to differ from the comparison group.

The infants of drug dependent mothers seem to be more active $($ median $=3 \cdot 67$, range $=2 \cdot 20-4 \cdot 75)$ than the reference children (median $=3.32$, range $=1.75$ $5 \cdot 25)$ at the age of 3 months $(p=0.05)$. This result remains when the preterm infants of drug dependent mothers are excluded from the analysis (median= $3 \cdot 75$, range $=2 \cdot 20-4 \cdot 75 ; p=0.05$ ). No differences were found at the age of 6 months.

Table 1 Examinations carried out, and numbers and mean ages of infants examined

\begin{tabular}{|c|c|c|c|c|c|c|c|}
\hline \multirow[t]{2}{*}{ Examination } & \multirow{2}{*}{$\begin{array}{l}\text { Age at which } \\
\text { examination } \\
\text { should be } \\
\text { carried out } \\
\text { (months) }\end{array}$} & \multicolumn{2}{|c|}{$\begin{array}{l}\text { Reference } \\
\text { infants }\end{array}$} & \multicolumn{2}{|c|}{$\begin{array}{l}\text { All infants born } \\
\text { to drug dependent } \\
\text { mothers }\end{array}$} & \multicolumn{2}{|c|}{$\begin{array}{l}\text { Infants born at full term } \\
\text { to drug dependent } \\
\text { mothers }\end{array}$} \\
\hline & & No & $\begin{array}{l}\text { Mean age } \\
\text { (months) }\end{array}$ & No & $\begin{array}{l}\text { Mean age } \\
\text { (months) }\end{array}$ & No & $\begin{array}{l}\text { Mean age } \\
\text { (months) }\end{array}$ \\
\hline Activity & 3 & 36 & $3 \cdot 0$ & 32 & $3 \cdot 0$ & 26 & $3 \cdot 0$ \\
\hline Touwen & 6 & 37 & 6.0 & 22 & $6 \cdot 0$ & 17 & $6 \cdot 0$ \\
\hline Activity & 6 & 37 & $6 \cdot 0$ & 30 & $6 \cdot 0$ & 23 & $6 \cdot 0$ \\
\hline Bayley & 6 & 37 & $6 \cdot 1$ & 27 & $6 \cdot 1$ & 21 & $6 \cdot 2$ \\
\hline Rothbart & 9 & 34 & $9 \cdot 0$ & 19 & $9 \cdot 2$ & 15 & $9 \cdot 3$ \\
\hline Touwen & 12 & 34 & $12 \cdot 1$ & 21 & $12 \cdot 9$ & 16 & $12 \cdot 0$ \\
\hline EEG & 12 & 34 & $12 \cdot 0$ & 23 & $12 \cdot 1$ & 18 & $12 \cdot 2$ \\
\hline Bayley & 12 & 34 & $12 \cdot 0$ & 26 & $12 \cdot 2$ & 21 & $12 \cdot 4$ \\
\hline
\end{tabular}


Table 2 Scores on electroencephalography

\begin{tabular}{llll}
\hline Score & $\begin{array}{l}\text { Reference } \\
\text { infants } \\
(n=34)\end{array}$ & $\begin{array}{l}\text { All infants born to } \\
\text { drug dependent } \\
\text { mothers }(n=23)\end{array}$ & $\begin{array}{l}\text { Infants born at full } \\
\text { term to drug dependent } \\
\text { mothers }(n=19)\end{array}$ \\
\hline $\begin{array}{l}1 \text { Normal } \\
2 \text { Borderline-a diffuse, somewhat irregular, little } \\
\text { developed pattern }\end{array}$ & 33 & 18 & 15 \\
$3 \begin{array}{l}\text { Suspect-a diffuse, slow, and irregular pattern } \\
\text { with some asymmetry }\end{array}$ & 1 & 3 & 2 \\
$4 \begin{array}{l}\text { Abnorma-a diffuse, slow, and irregular pattern } \\
\text { with focal or paroxysmal aspects, or clean } \\
\text { asymmetry, or both }\end{array}$ & 0 & 1 & 1 \\
\hline
\end{tabular}

Table 3 Results of the Bayley scale at 6 months

\begin{tabular}{|c|c|c|c|c|c|c|}
\hline & \multicolumn{2}{|c|}{ Reference infants $(n=37)$} & \multicolumn{2}{|c|}{$\begin{array}{l}\text { All infants born to } \\
\text { drug dependent mothers }(n=27)\end{array}$} & \multicolumn{2}{|c|}{$\begin{array}{l}\text { Infants born at full term to } \\
\text { drug dependent mothers }(n=21)\end{array}$} \\
\hline & $\begin{array}{l}\text { Median } \\
\text { score (range) }\end{array}$ & $\begin{array}{l}\text { No who scored } \\
\text { lower than } 1 S D \\
\text { below the mean }\end{array}$ & $\begin{array}{l}\text { Median } \\
\text { score (range) }\end{array}$ & $\begin{array}{l}\text { No who scored } \\
\text { lower than } 1 S D \\
\text { below the mean }\end{array}$ & $\begin{array}{l}\text { Median } \\
\text { score (range) }\end{array}$ & $\begin{array}{l}\text { No who scored } \\
\text { lower than } 1 S D \\
\text { below the mean }\end{array}$ \\
\hline $\begin{array}{l}\text { Mental } \\
\text { development index } \\
\text { Psychomotor }\end{array}$ & $105(83-150)$ & 1 & $102(90-133)$ & 0 & $102(90-126)$ & 0 \\
\hline development index & $115(72-150)$ & 4 & $121(81-150)$ & 1 & $121(81-150)$ & 1 \\
\hline
\end{tabular}

Table 4 Results of the Bayley scale at 12 months

\begin{tabular}{|c|c|c|c|c|c|c|}
\hline & \multicolumn{2}{|c|}{ Reference infants $(n=34)$} & \multicolumn{2}{|c|}{$\begin{array}{l}\text { All infants born to } \\
\text { drug dependent mothers }(n=26)\end{array}$} & \multicolumn{2}{|c|}{$\begin{array}{l}\text { Infants born at full term to } \\
\text { drug dependent mothers }(n=21)\end{array}$} \\
\hline & $\begin{array}{l}\text { Median } \\
\text { (range) }\end{array}$ & $\begin{array}{l}\text { No who scored } \\
\text { lower than } 1 S D \\
\text { below the mean }\end{array}$ & $\begin{array}{l}\text { Median } \\
\text { (range) }\end{array}$ & $\begin{array}{l}\text { No who scored } \\
\text { lower than } 1 S D \\
\text { below the mean }\end{array}$ & $\begin{array}{l}\text { Median } \\
\text { (range) }\end{array}$ & $\begin{array}{l}\text { No who scored } \\
\text { lower than } 1 S D \\
\text { below the mean }\end{array}$ \\
\hline \multirow{2}{*}{$\begin{array}{l}\text { Mental } \\
\text { development index } \\
\text { Psychomotor } \\
\text { development index }\end{array}$} & $111(87-150)$ & 0 & $108(79-137)$ & 1 & $109(79-137)$ & 1 \\
\hline & $114(90-150)$ & 0 & $112(68-150)$ & 2 & $110(68-150)$ & 2 \\
\hline
\end{tabular}

When the children were 9 months old there were no differences among the groups in degree of activity as judged by their parents or guardians on the infant behaviour questionnaire. The groups might differ slightly on the 'duration of orienting' of the infants (reference group-median $=3.44$, range $=2 \cdot 18-5 \cdot 27$; infants of drug dependent mothers-median $=4 \cdot 00$, range $=2 \cdot 00-5 \cdot 64, p=0 \cdot 08$ ), but this is more obvious when only the data on the subgroup born at full term are analysed (median $=4 \cdot 11$, range $=2 \cdot 00-5 \cdot 64, p=0 \cdot 03$ ).

At neither time did differences appear between the infants of drug dependent mothers and the reference group on the Bayley scales (tables 3 and 4). When the preterm infants of drug dependent mothers were excluded no differences were found either.

\section{Discussion}

The results of this study show one significant difference between infants of drug dependent mothers and reference infants after the neonatal period, when most of the infants had to go through a period of withdrawal ( $80 \%$ needed treatment). At the age of 3 months the infants of drug dependent mothers are more active than the reference group. By the end of the neonatal period the infants of drug dependent mothers tended to be more active. ${ }^{11}$ The results of these examinations possibly indicate symp- 
toms of the subacute abstinence syndrome, such as irritability. Differences were no longer found when the children were 6 months old.

Nor did the children differ in amount of activity at the age of 9 months as judged by the parents on the temperament questionnaire; the only factor that showed a tendency to differ was 'duration of orienting'. Infants of drug dependent mothers were better able to pay attention to a single object for extended periods of time than the reference infants. Other workers reported a group of infants exposed to methadone, but not a group of infants of drug dependent mothers who used only street drugs like heroin, as being less attentive than a drug free comparison group at nine months. In that study, however, attention was judged on the infant behaviour record of the Bayley scales. ${ }^{5}$

The evaluations of the electroencephalograms at one year showed that two infants of drug dependent mothers had abnormal or suspect electroencephalograms, and the results indicated that the groups tended to differ. The difference was, however, much less obvious than in the neonatal period, when almost $30 \%$ of infants of drug dependent mothers had suspect or abnormal electroencephalograms compared with two reference children $(6 \%){ }^{11}$

At the ages of 6 and 12 months the infants of drug dependent mothers did not differ from the comparison group on the neurological examination according to Touwen or on the Bayley scales of infant development. The Bayley scores indicate that the children in general were functioning within the normal range. Looking specifically at poorly functioning infants, with scores lower than one standard deviation below the mean, infants of drug dependent mothers did not seem to fare worse than the reference children (tables 3 and 4). The psychomotor scores of infants of drug dependent mothers at 6 months (with a median of 121) supported the notion of rapid motor development in early infancy; by the end of the first year this group of infants of drug dependent mothers showed no evidence of delay in motor development, contrary to the results of other investigators. ${ }^{9}$

Loss of subjects is a special problem in this area of research, but it did not seem to influence the study crucially. ${ }^{18}$ The dropout rate compared favourably with that of other studies on the development of infants of drug dependent mothers. ${ }^{46}$ Furthermore, although five parents left the project during the study, they do not seem to be a specific group, like the 'worst addicts.' They were distinguished most by the fact that two of their children did not show any withdrawal symptoms. Of the other parents, some came irregularly and two of them did not come at all, so only the measurements at home (activity observations) were completed for them. Obviously many parents in the infants of drug dependent mothers group also had difficulty in filling in and returning the infant behaviour questionnaire.

In this study infants of drug dependent mothers are compared with a group of children born at full term. This reference group physically had a good start in life (all born spontaneously and full term), and their mothers had not used hard drugs, nor did they have to cope with other social problems that go with the life style of addicts. Nevertheless, these groups of children only differ in amount of activity at the age of 3 months, an aspect of behaviour which could indicate subacute withdrawal symptoms in infants of drug dependent mothers. Perhaps it should be stressed that tests of infants often have limited predictive value, and longer follow up remains necessary for an adequate impression of development of infants of drug dependent mothers. Over the first year, however, the development of infants of drug dependent mothers did not seem to diverge particularly from that of the reference group.

This study was supported by a grant of the Praeventiefonds, No 28-856.

\section{References}

1 Deren, S. Children of substance abusers: a review of the literature. J Subst Abuse Treat 1986;3:77-94.

2 Desmond MM, Wilson GS. Neonatal abstinence syndrome: recognition and diagnosis. Addictive Diseases: an International Journal 1975;2:113-21.

3 Chasnoff IJ, Burns KA, Burns WJ, Schnoll SH. Prenatal drug exposure: effects on neonatal and infant growth and development. Neurobehav Toxicol Teratol 1986;8:357-62.

4 Johnson LH, Diano A, Rosen TS. 24-month neurobehavioural follow-up of children of methadone-maintained mothers. Infant Behavior and Development 1984;7:115-23.

5 Wilson GS, Desmond MM, Wait RB. Follow-up of methadone treated and untreated narcotic-dependent women and their infants: health, developmental and social implications. J Pediatr 1981;98:716-22.

${ }^{6}$ Strauss ME, Starr RH, Ostrea EM, Chavez CJ, Stryker JC. Behavioral concomitants of prenatal addiction to narcotics. J Pediatr 1976;80:842-6.

7 Kaltenbach K, Finnegan LP. Neonatal abstinence syndrome, pharmacotherapy and developmental outcome. Neurobehav Toxicol Teratol 1986;8:353-5.

* Ramer CM, Lodge A. Clinical and developmental characteristics of infants of mothers on methadone maintenance. Addictive Diseases: an International Journal 1975;2:227-34.

9 Strauss ME, Reynolds KS. Psychological characteristics and development of narcotic-addicted infants. Drug Alcohol Depend 1983;12:381-93.

10 Cohen J. Statistical power analysis for the behavioral sciences. New York: Academic Press, 1977.

1 Baar AL van, Fleury P, Soepatmi S, Ultee CA, Wesselman PJM. Neonatal behaviour after drug dependent pregnancy. Arch Dis Child 1989;64:235-40.

12 Touwen BCL. Neurological development in infancy. Clinics in developmental medicine No 58. London: Heinemann, 1976. 
${ }^{12}$ Schaffer HR. Activity level as a constitutional determinant of infantile reaction to deprivation. Child Dev 1966;37:595-602.

14 Rothbart MK. Measurement of temperament in infancy. Child Dev 1981;52:569-78.

${ }^{15}$ Bayley N. Bayley scales of infant development. New York: Psychological Corporation, 1969.

${ }^{16}$ Meulen BF ven der, Smrkovsky M. De Bayley OntwikkelingsSchalen (BOS 2-30). Lisse: Swets and Zeitlinger, 1983.

${ }^{17}$ Siegel S. Nonparametric statistics for the behavioral sciences. Tokyo: McGraw-Hill, 1956.
18 Aylward GP. Methadone outcome studies: is it more than the methadone? J Pediatr 1982;101:214-5.

Correspondence and requests for reprints to $\mathrm{Dr} \mathrm{A} \mathrm{L}$ van Baar, Academisch Medisch Centrum, Department of Neonatology, H4-241, Meibergdreef 9, 1105 AZ Amsterdam, The Netherlands.

Accepted 7 July 1988 